\title{
Industrial relations legislation in 1984
}

\author{
W C Hodge*
}

This note outlines and discusses the major changes in industrial relations legislation to take place in New Zealand during 1984.

The year 1984 was characterised more by electoral campaign than by legislative passage. The snap election of 14 July 1984, which produced the only mid-year change of government in recent New Zealand history, abridged the legislative programme of the outgoing National Government, and left the incoming Labour Government with insufficient time to effect its own statutory schedule.

There were, therefore, 2 much abbreviated parliamentary sessions in 1984, and they will be discussed here separately and labelled Mark I (National) and Mark II (Labour).

\section{Mark I (National)}

The outgoing National Party administration of Sir Robert Muldoon completed the third reading of and gubernatorial signature to only 2 bills before the June break-up of the fortieth Parliament. One, the Imprest Supply Act, is a standard and typical annual legislative event; the second, the Whangarei Refinery Expansion Project Disputes Act (hereafter, the WREPDA), is absolutely unprecedented and unique for any legislative year in any Commonwealth country.

Before surveying the background of WREPDA, its preamble and 4 provisions will explain its peculiar significance. The WREPDA is enacted because:

\begin{abstract}
... work on the expansion of the Whangarei Refinery at Marsden Point is effectively at a standstill: and [because] it is in the public interest that work on the expansion of that refinery be resumed as soon as possible and continued and that provision be made for compliance with terms and condtions of employment and for the observance of procedures for settling industrial disputes that arise in relation to that work.
\end{abstract}

Four of the salient provisions, with their legalisms paraphrased, are set out below:

(1) It statutorily directs all project workers to report for work on 13 June 1984, with a penalty imposed on those who fail to comply and who cannot prove a reasonable excuse (sections 3 and 7);

(2) it adds terms and conditions to the collective agreement made by the parties; (section $2(3))$;

(3) it names 8 individuals, all engineering scaffolders, who are not to be discriminated against by other workers (section $2(3)(a))$; and

* Senior lecturer in Law, University of Auckland 
(4) it enables police constables above the rank of sergeant to direct the placement of pickets, with potential penalties of 3 months' goal or a fine up to $\$ 1000$ (section 11).

Since the background to the legislation is rather complex, it may be appropriate to set out first the details of matters which led to the site disputes of May-June 1984 before dealing with legislation itself.

New Zealand's only facility for "cracking" heavy crude oils into fuel oil, diesel, and petrol products is the refinery at Marsden Point, on the south-westerly entrance to Whangarei Harbour. That facility is wholly owned by the NZ Refining company (NZRC), which in turn is owned (68.6 percent) by the major oil companies (Mobil, 19.2 percent; Shell, 17.1 percent; BPNZ 15.1 percent; Caltex, 8.6 percent; Europa, 8.6 percent) and individual investors ( 31.4 percent).

The owners of NZRC, together with the government, recognised a need to expand the Marsden Point facility to:

(1) increase production quantitatively;

(2) increase the range of raw crudes that could be refined; and

(3) broaden the range of product mix, to include higher octane kerosene and aviation fuels

The NZRC awarded the expansion project contract (then estimated to cost \$1035 million) to an overseas joint venture, Badger-Chiyoda, based respectively in The Hague Holland; and Yokohama, Japan. Badger-Chiyoda as the main contractor then sub-contracted to Joint Venture II (JVII), which is a partnership of Badger-Chiyoda itself and "the consortium", being 5 of New Zealand's largest construction companies (Fletcher Construction, McConnell Dowell, Robert Stone, Wilkins and Davies, and Downer).

Labour relations at the site in early 1984 were taut, for 2 reaons. First, an inherent feature of any "Think Big" project was a national spotlight, with all actors conscious of their leading roles on a nation-wide, precedent-setting stage. Therefore, as large as the project itself was, each site dispute was played out in a far larger context. There were no quiet solutions; there were no insignificant disputes. Second, one of the unresolved matters in dispute concerned accommodation and accommodation allowances. Many sub-contractors were happy to pay an accommodation allowance based on an average Whangarei rental, while union leadership was concerned that such cash in hand, as opposed to guaranteed company housing, would compromise the bargaining position of any dismissed worker who wished to contest that dismissal.

The catalyst which activated the unstable elements described above was the double legal persona of one of the aforementioned sub-contractors, Bob Duncan Scaffolders (BDS). The sub-contractor, BDS, had given notice of concurrence with the site agreement and had been accepted in turn. Eight employees of BDS, all scaffolders, were observed to be working on site on a Saturday, in apparent violation of an informal site ban on overtime. Furthermore their employment may have been for the non-concurring Whangarei Scaffolding Limited (WSL), an incorporated version of BDS. It was this event which triggered the site walk-out, the televised clashes between pickets and police, and scenes of a semi-armoured van conveying the 8 scaffolders to and from the site through mass
pickets.

It was in this atmosphere of crisis that the WREPDA was passed, and signed on 12 June 1984. The language, and "feel" of the legislation is that of wartime emergency "workers shall report for work on 13 June" [emphasis added] - and the imperative/ punitive clauses have the ring of indentured servitude. As a political document it has the odour of a "who's going to run the country - a few union leaders or the elected government of New Zealand?" pre-election manifesto.

On the other hand, the vast majority of the workforce did return to work on the appointed day; productivity did increase significantly after the return to work; and the penalty for non-return (in section 7) was a mere 4 months' disentitlement to the unemployment benefit (especially insignificant, in light of the Social Security Act provisions which allow up to 12 weeks' standing down time for voluntary unemployment in any case); and many, not all on the management side, might be heard to say that workers took 
the Act as an opportunity to save face and return to work.

Taken as a whole, the WREPDA simply dictates that both parties will abide by the agreement they already agreed to abide by. The new terms, set out in section 2(3), express terms implied in any contract of employment and contain nothing oppressive. Paragraph (b), for example, purports to forbid "dangerous conduct" towards any of the 8 scaffolders named in paragraph (a), but intentional or negligent dangerous conduct toward a coworker would be misconduct and grounds for dismissal in any contract of employment, and may well be a crime.

In any event, in this writer's opinion, the WREPDA is of no significance to industrial law and industrial relations generally. It has no legal import to anyone but the parties to the JVII Collective Agreement and the project workers covered thereby. It will soon be relegated to the musuem of parliamentary oddities, a historical hiccup of the 1984 electoral campaign.

\section{Mark II (Labour)}

Perhaps the most significant aspect of the 1984 session of the forty-first NZ Parliament was the Sherlock Holmesian dog who barked in the night (Sir A C Doyle, Silver Blaze), or, the conspicuous absence of Labour's promised repeal of the "voluntary unionism" of National's Industrial Relations Amendment Act 1983, as reinforced by the Wages Protection Act 1983. As a matter of practicality, the repeal was a step best done quickly, if done at all.

Thousands of contracts of employment have been entered into since 1 February 1984, contracts which have never included an unqualified preference clause and the complications of reversal have thereby intensified. (The European Court, in Young, James and Webster v UK (1981) would probably have distinguished a contract where the state was directing compulsory membership as a fresh term, as opposed to a contract where compulsory membership was being reintroduced after a short gap). In addition, the Human Rights Commission (1985) in its discussion paper has suggested that the right to associate includes a negative right not to be associated by compulsion. ${ }^{1}$ And as the decision of the European Court of Human Rights in Young, James and Webster becomes better known in New Zealand political opposition to unqualified preference will increasingly take the form of principled opposition. Perhaps Labour found some utility in delay during the wage round as an inducement to the trade union movement to adhere to government guidelines.

The Labour Government did pass an Industrial Relations Amendment Act in 1984, (hereafter, IRAA) and consequential amendments to the Agricultural Workers Act 1977, the Aircrew Industrial Tribunal Act 1971, and the Waterfront Industry Act 1976. These 3 consequential amendments are described below, following a brief discussion of the IRAA.

The principal features of the IRAA are adjustments to institutional machinery, not substantive changes in parties' rights and liabilities. Section 3 inserts a new part IIA, with 12 sections, into the principal Act to provide a statutory basis for an annual summit conference of the central wage fixing organisations. Section 16A directs that the Minister of Labour shall arrange a Tripartite Wage Conference, each year, between the government, the central organisations of both public and private employees (in CSU and the FOL or their successors in interest), the central organisation of employers and the State Services Co-

1. "The law should protect rights to freedom of speech and association but should not compel anybody to exercise them. Accordingly, as far as trade unions and human rights are concerned, the protection of human freedom should come first. From a human rights point of view, the law should encourage, but no coerce, men and women to take an active part in determining conditions in which they live and work. Equally the law should protect people from being constrained to join any association including an industrial union". (p. 11) 
ordinating Committee. Attendance is not compulsory for these named parties but section $16 \mathrm{~A}(4)$ provides that no meeting shall take place if any one of the parties does not appear. The minister must also give public notice of the Tripartite Wage Conference (section $16 \mathrm{E}$ ), and must make submissions made by any person available to conferees. Each Tripartite Wage Conference, which is to be chaired by a Minister of the Crown (section 16B) shall be a forum for consultations about "the economic environment" and "the government's economic policies" as they effect wages and conditions of employment (section $16 \mathrm{G})$. The consultations must relate to inflation, income distribution, the competitiveness of New Zealand industry, the implications of the government policies, unemployment, and the interests of low-paid workers (section 16G and H). The Tripartite Wage Conference may make conclusions and recommendations, if arrived at unanimously (section $16 \mathrm{I}$ ), but to the extent that any such recommendation is a percentage "guideline", that percentage shall operate as a guide to wage-fixing tribunals, but shall not have "any greater standing". (Section 16J).

In addition to this potentially useful annual summit conference, the 1984 IRAA also makes institutional adjustments to the constitution of the Arbitration Court, perhaps anticipating a 4 judge court, by providing for temporary nominated members, as well as acting nominated members (as per the 1977 IRAA). Section 7 of the 1984 Act expands, and markedly changes the concept of voluntary settlements (section 65 of the principal Act) by allowing reference to the court on unresolved issues; issues then to be treated as part of the voluntary settlement. Section 8 of the 1984 Act extends the usefulness of composite agreements (a special type of voluntary agreement under section 66 of the 1973 Act) by allowing latecoming unions and employers to become parties to a registered agreement during its currency, and by allowing a union to withdraw by giving 7 days' notice (section 66(11)). An interesting feature of conciliated settlements, per section 82 of the principal Act, as inserted by section 10 of the 1984 IRAA, is a requirement for the assessors to memorialise any wage increases, for reasons for such increase, and a quantification of the components that go into such increase, such memorandum to be delivered to the Secretary of Labour, the central organisations and the Court. Section 13 of the 1984 IRAA amends section 84 of the principal Act by prohibiting a withdrawal (at the reference stage) under section 76 of the principal Act.

Perhaps the primary substantive changes of note, contained in section 16 and 17 of the 1984 IRAA, amend, respectively, section 115 ("Dispute of Rights") and section 117 ("personal grievances") of the principal Act by allowing the parties to measure and taylor their own disputes clause and personal grievance machinery, in lieu of the standard clauses set out in section 116 and section 117(4). The standard clauses will still be inserted into awards and agreements if the parties choose not to fashion one of their own.

Finally, in a marked change in political-economic policy, a new section $86 \mathrm{~A}$ directs the court, when making an award under section 86 , to have regard to "the supply and demand factors for the skills of the workers" concerned, and not to be bound by historical precedent and practice. Other factors the court is directed to take into account include fairness and equity, changes in job content, changes in productivity and technology, and relativities.

The consequential amendments, referred to above, in relation to the Agricultural Workers Act, the Aircrew Industry Tribunal Act, and the Waterfront Industry Act, are of a piece with the just noted section $86 \mathrm{~A}$. The respective wage-fixing tribunals in the 3 industries are to take account of supply and demand factors and are not be bound by historical precedent and practice.

In sum, then, it can be argued that National's 1984 legislation (the WREPDA) is characterised by intervention and the substitution of state direction for agreement between the parties. Labour's 1984 legislation (the IRAA and 3 consequential amendments) is characterised by loosening restraints on bargaining, giving greater scope for parties to create their own dispute resolution machinery, and directing wage fixers to follow the market place instead of historical practice. 


\section{References}

Human Rights Commission (1985) Membership of Unions and the right to freedom of association Wellington.

\section{List of cases}

Young, James and Webster v UK (1981) IRLR 408. 